Scholarship Repository

University of Minnesota Law School

Articles

Faculty Scholarship

1994

\title{
UNESCO Human Rights Procedure: An Evaluation
}

David Weissbrodt

University of Minnesota Law School, weiss001@umn.edu

Rose Farley

Follow this and additional works at: https://scholarship.law.umn.edu/faculty_articles

Part of the Law Commons

\section{Recommended Citation}

David Weissbrodt and Rose Farley, UNESCO Human Rights Procedure: An Evaluation, 16 HUM. RTS. Q. 391 (1994), available at https://scholarship.law.umn.edu/faculty_articles/246.

This Article is brought to you for free and open access by the University of Minnesota Law School. It has been accepted for inclusion in the Faculty Scholarship collection by an authorized administrator of the Scholarship Repository. For more information, please contact lenzx009@umn.edu. 


\title{
The UNESCO Human Rights Procedure: An Evaluation
}

\author{
David Weissbrodt \& Rose Farley*
}

\section{INTRODUCTION}

The United Nations Educational, Scientific, and Cultural Organization (UNESCO) released a report in March 1993 summarizing the results of its procedure which was established in $1978^{1}$ to handle complaints from imprisoned authors, educators, scientists, and other persons suffering human rights violations within UNESCO's purview. The report provided a rare public statement about this aspect of UNESCO's human rights work; unfortunately, the reported data provide merely an overview of the outcome of complaints filed under the procedure, and do not critically examine ${ }^{2}$ the cases or the procedure's efficacy.

The report, for example, states that the UNESCO Committee on Conventions and Recommendations examined a total of 414 cases between 1978 and 1993, of which it settled 241 individual cases. During that period 129 individuals were either released or acquitted, twenty were authorized to leave and thirty-four to return to the state concerned, twenty-four were able to resume the employment or activity from which they had been banned, and eleven were able to resume a banned publication or broadcast. ${ }^{3}$ While this report indicates some of the usefulness of the procedure, it

* The authors wish to thank Tracy Bach for her assistance in the preparation of this article.

1. 104 UNESCO Executive Board, UNESCO Doc. 104 EX/Decision 3.3 (Paris, 24 April-9 June 1978).

2. For examples of such critical evaluations, see, e.g., Philip Alston, The United Nations and Human RICHTS 12-21 (1992) (criteria for assessing effectiveness of UN human rights efforts); Dinah Shelton, Utilization of Fact-Finding Missions to Promote and Protect Human Rights: The Chile Case, 2 Hum. Rrs. L.J. 1 (1981); David Weissbrodt \& Maria Bartolomei, The Effectiveness of International Human Rights Pressures: The Case of Argentina, 1967-1983, 75 Minn. L. Rev. 1009 (1991).

3. UNESCO Doc. 141 EX/6 (Item 3.3 of the provisional agenda regarding the name and terms of reference of the Committee on Conventions and Recommendations at its $141 \mathrm{st}$ session, March 1993), at 4. 
does not go far enough. Due to the secrecy that dominates the process, little is known about the substantive and procedural details of the Committee's caseload. Questions remain concerning what happened to the alleged victims in the "unsettled" cases, such as how long those seeking redress had to wait for help, and once received, what kind of response the victims received.

This article attempts to begin filling the gap in critical analysis of the UNESCO procedure by reviewing the handling and outcome of the sixtyfour cases presented to the Committee between 1980 and 1991. ${ }^{4}$ This study sample, involving thirty-six countries, ${ }^{5}$ does not include any case currently pending before the Committee. The results of the study are instructive; of the sixty-four cases, the Committee declared five "admissible" and seventeen "inadmissible," keeping the remaining forty-two cases pending while considering their admissibility - before deleting them from their list.

A review of the outcome of the sixty-four cases reveals that the procedure has been only partially successful in restoring the rights of the victims represented in the cases. Of the 190 individuals in these cases who were victims of human rights violations relating to education, science, culture, or communication, the situations of ninety-three had improved following action taken by the Committee. Of these ninety-three individuals, sixty-three were released either from prisons or re-education camps, four received passports, twenty-two were rehired to their former positions, three remained in jail but were granted sentence reductions, and one was returned from exile. Of the remaining ninety-seven individuals, ten remained imprisoned and one died while in detention. The fate of the other eighty-six individuals is unknown.

Although the procedure has helped to better the situations of ninetythree individuals, the results of this study suggest that the procedure itself needs improvement. First, the procedure does not reach enough cases; it has been so shrouded in secrecy that very few people have sought relief. Further, the ninety-three individuals represent less than half of the total number of individuals involved in the sixty-four cases. Second, one cannot conclude that the UNESCO procedure actually brought about the improvements of the victims' situations. Political developments within the countries

4. The cases are now closed. The authors are grateful to the International Human Rights Law Group and other sources for their cooperation in obtaining information about the cases.

5. These include Afghanistan, Argentina, Benin, Bulgaria, Central African Republic, China, Cuba, Czechoslovakia, Egypt, El Salvador, Haiti, Indonesia, Iran, Italy, Jordan, Kenya, Laos, Malawi, Morocco, Myanmar, Nepal, Nigeria, Pakistan, Paraguay, Peru, Romania, Rwanda, Somalia, South Korea, Sudan, Turkey, Uruguay, Soviet Union, Vietnam, Yugoslavia, and Zaire. 
concerned were also decisive factors in determining the eventual fate of the victims. Third, the procedure is too slow. Many of the ninety-three individuals had to wait several years before their situations improved. Fourth, the procedure lacks accountability. The UNESCO Committee often did not verify government statements with the case authors to ensure that the victims were actually released.

Finally, the UNESCO procedure, while ameliorating some victims' conditions, has failed to ensure the protection of victims' rights relating to UNESCO's field of competence-specifically freedom of expression and association. Cases may be submitted under the procedure by teachers, artists, poets, authors, and other individuals whose rights to education, to share in scientific advancement, to participate in cultural life, and to information, including freedom of expression, have been violated. In the sixty-four cases, victims were detained in prison or fired following publication of their writings or following participation in strikes or other types of nonviolent, public forms of expression. In some cases, victims were arrested simply for their actual or alleged membership in an organization. Although the UNESCO Committee may have helped to assure these victims' release from prison, the Committee then usually dropped the cases rather than pressing for the restoration of other rights within its mandate, such as the right to publish one's writings or to demonstrate peacefully. In only two cases did the Committee attempt to guarantee the victims' right to freedom of expression.

This article contains three sections. The first section overviews the UNESCO complaints procedure and highlights the structural defects that affected the handling of the sixty-four cases. The second section, which analyzes the procedure followed by UNESCO in the sixty-four cases, is divided into three categories: (1) cases declared admissible; (2) cases declared inadmissible; and (3) cases kept pending without being declared admissible. The third section concludes by assessing the effectiveness of the procedure and offering recommendations to improve it.

\section{OVERVIEW OF THE UNESCO COMPLAINTS PROCEDURE}

Although the UNESCO complaints procedure is not well publicized, functions in obscurity, and fails to explain its results, the process for utilizing it is well-documented. ${ }^{6}$ Once UNESCO receives a communication, the Director-General (DG) completes four steps before forwarding it to the

6. See 104 UNESCO Executive Board, UNESCO Doc. 104 EX/Decision 3.3 (Paris, 24 April9 June 1978). 
Committee. First, the DG acknowledges receipt of the communication and informs its author of the conditions of admissibility.' Second, the DG ensures that the communication's author has no objection to bringing the communication and the author's name before the Committee. Third, once the author has given permission to proceed, the DG sends the communication to the government concerned, informing it that the Committee will review the communication concurrently with any reply submitted by the government. Fourth, the DG sends the communication to the Committee with any additional information from the author.

Upon receiving the communication, the Committee first is to decide whether to declare it admissible, thereby warranting further action by the Committee. Ten conditions govern the determination of admissibility, including that:

1. communications must not be anonymous;

2. only a victim or group of victims of an alleged violation, or a person, group of persons, or a nongovernmental organization (NGO) having reliable knowledge of those violations, may author a communication;

3. alleged violations must concern human rights violations falling under UNESCO's competence in the fields of education, science, culture, and information, and may not exclusively concern other considerations;

4. communications must be compatible with international instruments in the field of human rights;

5. communications must not be manifestly ill-founded and must appear to contain relevant evidence;

6. communications must not be offensive or abuse the right to submit them, although they may be considered if they meet all other admissibility criteria after excluding the offensive or abusive parts;

7. communications may not be entirely based on information disseminated in the mass media;

8. communications must be submitted within a reasonable time period following the occurrence of the facts of the case or the point at which these facts become known;

7. For a specific listing of these criteria, see infra note 8 and accompanying text. 
9. communications must indicate whether attempts to exhaust available domestic remedies have been made and the results of them, if any; and

10. communications relating to matters already settled by the states concerned in accordance with the principles set forth in the Universal Declaration of Human Rights and the International Covenants on Human Rights shall not be considered. ${ }^{8}$

If a communication does not meet any of these conditions, the Committee may declare it inadmissible and drop it from further consideration. The Committee may, however, keep a communication on its agenda if it desires more information to determine the question of admissibility. If a communication should meet all of the conditions, then the DG notifies the authors and governments who are parties of the Committee's decision to declare the communication admissible.

Once beyond the threshold question of admissibility, the Committee considers the substantive merits of the communications. Unlike the explicit criteria outlined for determining admissibility, this stage appears guided by no published conditions. Hence, if the Committee determines that the communication does not merit further consideration, it dismisses the complaint and notifies the author and the government of its actions. If the Committee should agree that the communication merits full consideration, it will act with the goal of "bring[ing] about a friendly solution designed to advance the promotion of the human rights falling within UNESCO's fields of competence." ${ }^{\prime 9}$ Such a "friendly solution" would settle the matter in a way satisfactory to the government and the complainant. The Committee then drafts a confidential report containing a summary of its findings and a set of recommendations, regardless of whether it has achieved a "friendly solution," and submits the report to the Executive Board at its regular sessions. The Board, which also meets in private, would be expected to adopt the Committee's reports.

This brief review of the UNESCO complaints procedure suggests the inherent, underlying tension between the admissibility and merits phases. In the first phase, the Committee is supposed to emphasize rule adherence and fact-finding, playing a quasi-judicial role because of the very nature of making the admissibility determination despite an explicit admonition in the UNESCO Constitution against judging the conduct of nations. ${ }^{10}$ In the

8. 104 UNESCO Executive Board, UNESCO Doc. 104 EX/Decision 3.3 (Paris, 24 April-9 June 1978), शा 14(a).

9. Id. ๆ $14(\mathrm{k})$.

10. Article 1, paragraph 3, of UNESCO's Constitution states that UNESCO is prohibited from "intervening in matters which are essentially within [the] domestic jurisdiction" of Member States. This clause was essentially written into paragraph 7 of 104 EX Decision 
second phase, the Committee is expected to return to the more cooperative and "friendly" nature that the procedure so heartily endorses, unless the cooperative approach fails."

This fundamental conflict in the nature of the Committee's work stems from unresolved discussions of the Committee's authority to address human rights violations at the time UNESCO created the procedure. In fact, the very language of the procedure ultimately adopted by the Executive Board embodies dual notions of a quasi-adjudicative process, modeled after the procedure of the European Commission of Human Rights ${ }^{12}$ and UN complaints procedures under ECOSOC resolutions $1235^{13}$ and $1503,{ }^{14}$ as well as one based on more cooperative mediation. ${ }^{15}$

Despite the apparent clarity and published nature of the criteria, the way in which the Committee construes the criteria remains a process shrouded in secrecy. ${ }^{16}$ The Committee's confidential meetings include

3.3, which states that UNESCO, "basing its efforts on moral considerations and its specific competence, should act in a spirit of international cooperation, conciliation and mutual understanding; and recalling that UNESCO should not play the role of an international judicial body."

11. As Philip Alston described it, "[t]he initial thrust of the procedure is towards the quiet resolution of human rights problems through the cooperation of the relevant organs of UNESCO and the state concerned." Philip Alston, UNESCO's Procedures for Dealing With Human Rights Violations, 20 Santa Clara L. Rev. 665, 695 (1980).

12. For a discussion of the European procedures, see Pieter van Dijk \& Godefridus J. H. van Hoof, Theory and Practice of the European Convention on Human Rights (2d ed. 1990); Mark W. Janis \& Richard S. Kay, European Human Richts Law (1990).

13. ECOSOC Res. 1235 (XLII), 42 U.N. ESCOR Supp. No. 1, at 17, U.N. Doc. E/4393 (1967).

14. ECOSOC Res. 1503 (XLVIII), 48 U.N. ESCOR Supp. No. 1A, at 8, U.N. Doc. E/4832/Add. 1 (1970).

15. Before establishing its procedure, UNESCO undertook a thorough comparative study of all existing human rights procedures. See 102 UNESCO Executive Board, UNESCO Doc. $102 \mathrm{EX} / 19$ (1977). The procedure is limited by a set of provisions, contained in UNESCO's Constitution and written into the procedure, that prohibit UNESCO from intervening in the domestic jurisdiction of states. Interestingly, there were only two cases in the study in which governments claimed that UNESCO was violating these clauses. In one case, the government concerned claimed that by asking questions about its domestic judicial procedures, the Committee was acting as an international judicial body. In the second case, the government concerned claimed that the case was a matter of domestic jurisdiction. The Committee, however, did not accept these government arguments and proceeded to consider the cases using the normal procedure. Currently the issue of noninterference in domestic jurisdiction is no longer considered to bar investigations of human rights violations. See Menno T. Kamminga, The Inter-State Accountability for Violations of Human Rights (1992).

16. Georges-Henri Dumont, former chair of the Committee, noted that with respect to its policy of keeping strict confidentiality, the Committee "is statutorily obliged to do so and, what is more, derives a substantial part of its effectiveness from the private nature of its working sessions." Georges-Henri Dumont, UNESCO's Practical Action on Human Rights, 122 INT'L Soc. ScI. J. 585, 588-89 (1989). Professor Karl Partsch indicated the demanding role of secrecy surrounding the procedure when he wrote "[I] a confidentialite absolue des travaux du Comité, y inclus de ses décisions, impose des limites strictes à 
government representatives who may attend to provide additional information or answer Committee member questions, while excluding the authors of communications. Also, the Committee may use any relevant information at the DG's disposal when considering a communication.

Nonetheless, at the time of its adoption, the procedure had several advantages over the European and UN complaints procedures. ${ }^{17}$ Those advantages included:

- wide access to individuals, groups, and nongovernmental organizations (NGOs);

- ability of NGOs to complain on behalf of victims;

- separate handling of each case throughout the procedure, rather than merging cases into a "situation";

- consideration of individual "cases" of human rights violations as well as "questions" of mass and flagrant violations;

- subjecting countries that have not ratified human rights treaties to its procedure; and

- the Committee's ability to use other sources of information when considering cases, including the power of the Executive Board to appoint fact-finding missions. ${ }^{18}$

Although an improvement at the time of its adoption, the UNESCO procedure has not progressively evolved the way other UN procedures have. ${ }^{19}$ UNESCO has not exploited the advantages written into the procedure. The procedures have not been implemented appropriately because the UNESCO process has not been subjected to the glare of public pressure,

l'auteur. Il n'est autorisé à citer ni les noms des auteurs ni celui des victimes des violations alleguées dans les communications ni enfin celui des Etats concernes." Karl Josef Partsch, La Mise en Oeuvre des Droits de l'Homme par l'UNESCO, 36 Annualre Francaise de Droit International 482, 485 (1990).

17. For a discussion of UNESCO's legal mandates and operations, see Alston, supra note 11; Dumont, supra note 16; Stephen Marks, UNESCO and Human Rights: The Implementation of Rights Relating to Education, Science, Culture and Communication, 13 TEXAs INT'L L. J. 35 (1977); Stephen Marks, The Complaint Procedure of the United Nations Educational, Scientific and Cultural Organization in Hurst Hannum, ed., Guide to International Human Richts Practice 86-98 (2d ed. 1992); Partsch, supra note 16.

18. See Alston, supra note 11 , at 695 .

19. For a discussion on the development and operation of resolutions 1235 and 1503 , see Frank Newman \& David Weissbrodt, International Human Rights: Law, Policy, and Progress 101-43 (1990); Manfred Nowak, Country-Oriented Human Rights Protection by the UN Commission on Human Rights and its Sub-Commission, 22 Netherlands Y.B. INT'L. L. 39 (1991). 
and because it has been quite isolated from more progressive developments in other international institutions.

Furthermore, in practice the Committee has mingled the admissibility phase and the later "friendly solution" stage. The Committee's flexible mandate to seek friendly solutions has intruded into the admissibility phase of the procedure. ${ }^{20}$ This lack of distinction between the two phases has caused the unwarranted rejection of cases and, more commonly, lengthy delays in the consideration of cases.

\section{REVIEW OF THE SIXTY-FOUR CASES}

A review of the sixty-four cases in this study reveals that the Committee rarely chose to declare cases admissible. Instead, it followed two distinct approaches in handling the cases. Most frequently, the Committee kept cases pending without making a determination of admissibility, operating under the belief that the longer a case remained pending, the greater the pressure on the government to seek a friendly solution. When following this approach, the Committee was most effective in obtaining an amicable solution, such as the granting of passports or the release and/or reemployment of victims. One should recall, however, that even in cases where an amicable solution was reached, the extent to which the Committee's actions were directly responsible cannot be fully determined. Political developments as well as the simple passing of time may have also contributed to the positive outcome of some cases. ${ }^{21}$

Following another approach, the Committee declared cases inadmissible under one or more of the ten defined criteria of admissibility. ${ }^{22}$ In these instances, the Committee proved unwilling to keep cases pending, making its finding of inadmissibility after a short number of examinations. In these instances, the Committee finds that the merits of the case do not warrant full

20. See Partsch, supra note 16 , at 498 (describing the need to consider the substance of a claim's merits when considering whether it is manifestly ill-founded or not: "Elle introduit, comme un préalable, un élément de grande portée dans l'examen de recevabilité et affaiblit en même temps l'importance de l'examen du fond .... En accomplie au cours de l'examen de la recevabilité, la troisième phase ne revêt pas la même importance que la deuxième phase.").

21. For example, the changes in governments and political systems in the former Czechoslovakia, Hungary, Russia, and other Eastern European countries have led to the release of political prisoners. See, e.g., Amnestr International Report 1 (1991) (describing changes in Eastern Europe in general); Amnesty International Report 79, 116 (1990) (noting that Czechoslovakia released at least thirty-six political prisoners, and Hungary at least seventy, in 1989).

22. See supra note 8 and accompanying text. 
examination and an amicable solution is unable to be achieved. The following subsections examine the outcomes of these sixty-four cases more fully, by dividing them into three categories: (1) cases declared admissible; (2) cases declared inadmissible; and (3) cases kept pending without being declared admissible.

\section{A. Cases Declared Admissible}

The Committee declared five cases admissible following a period of keeping them pending, but later closed them. Theoretically, having a case declared admissible is desirable because such a decision guarantees that the case will be more closely examined by the Committee. But the five cases declared admissible show that such a decision does not necessarily increase a case's chances for success.

Three of these five cases concerned one Latin American country. These three cases represent the Committee's most extensive efforts to bring about a friendly solution to a case in this study sample. Pursuant to its favored approach, ${ }^{23}$ the Committee kept these cases pending despite the government's requests to close them. As a result of the government's persistent failure over many years to provide specific information on the cases, the Committee declared them admissible. The Committee kept its investigation into the cases confidential, maintaining private dialogues with the government in the hope that such "pressure" would persuade it to cooperate, rather than establishing a fact-finding mission, the results of which would have been made public.

Yet despite the Committee's attempts, it failed to help the victims, largely due to the extreme length of time these cases remained before the Committee. The first case, submitted to UNESCO in 1980, was examined during nineteen semi-annual Committee sessions for nine and one half years. The second case, submitted to UNESCO in 1981, was examined during seventeen Committee sessions for eight and one half years. Both cases were declared admissible in 1984. The third case, submitted to UNESCO in 1985, was examined during nine Committee sessions. The

23. In a 1984 self-study, members of UNESCO's Executive Board acknowledged this practice and concluded that it was not problematic.

"(E)xperience has in fact shown that postponement of the examination of a communication to the subsequent session is not detrimental to the alleged victim, since in most cases humanitarian approaches are made by the Director-General, consultations take place, and various prominent people offer their good offices in the mean time."

120 UNESCO Executive Board, UNESCO Doc. 120 EX/17 Item 5.5 .1 at 13 (10 September 1984). 
three cases were eventually deleted from the Committee's list without any evidence of result or any judgment on the merits.

As mentioned earlier, an expected advantage of the UNESCO procedure was the ability of the Committee to appoint fact-finding missions to examine "questions" of large-scale human rights violations. ${ }^{24}$ Such a mission could have helped the Committee in its handling of the three Latin American cases, especially because the results of the mission would have been made public. Instead, the Committee attempted to settle the cases diplomatically and non-publicly. During the decade in which the three cases were subject to the UNESCO procedure, the Committee decided to send one of its members to the country-concerned in order to establish a dialogue with government officials about the country's human rights practices. This visit was confidential and not a public "fact-finding" mission. The results of the mission were reported to the Committee and the executive board in private. The cases' author was notified that the mission took place, but was not informed about its results even though its three cases were supposed to be discussed as part of the mission.

The Committee's decision to send a representative to the country signifies its strong commitment to bring about a positive solution to the cases. Despite these private efforts, however, the cases remained pending for nearly a decade without success. The three cases exemplify the limitations of the Committee's diplomatic, non-public approach in cases where a real "situation" of human rights violations exists, and provide a concrete example of the Committee's failure to appoint fact-finding missions. ${ }^{25}$ When following this approach, however, such confidentiality is

24. In 1980, while commenting on the overall cooperative nature of the UNESCO procedure, Alston wrote: "[n]evertheless, while initially seeking to minimize the opportunities for politicization of the relevant issues, the procedure acknowledges that, in the last resort, the pressure of international public opinion, brought about through the full glare of publicity, may be required in order to achieve the procedure's objectives." Alston, supra note 11 , at 695 .

25. In fact, the Executive Board has never appointed a fact-finding mission to investigate "questions" of massive human rights violations. Georges-Henri Dumont, a former Chairman of the UNESCO Committee has stated,

We have deliberately confined ourselves here to the examination of individual cases. Although it is true that the Committee is empowered to forward to the Executive Board and General Conference, for public consideration of questions relating to 'massive, systematic and flagrant violations,' it has so far never done so.

UNESCO, The Quest for Human Rights: UNESCO'S Ultimate Goal, 16 UNESCO Sources 1 (June 1990); see also Partsch, supra note 17, at 503 (explaining that the public nature of questions inspires conservatism in its use: "Il appartient au Conseil exécutif de décider s'il faut ou ne faut pas, examiner en séance publique tout 'question' qui lui serait transmise par le Comité, mais en tout état de cause, le Comité devrait faire preuve d'une extreme prudence avant de décider de considerer un problème comme une 'question' et de la transmettre au Conseil et il devrait prendre cette décision qu'en dernier recours."). 
confused by an excessive UNESCO preoccupation with secrecy and precludes UNESCO's accountability to the world community regarding the work of the Committee.

These three cases point also to the Committee's failure to capitalize on its expected advantage of handling cases separately throughout the procedure without merging them into situations. During its examination of the three cases relating to a Latin American country, the Committee appears to have merged the cases together for consideration. The Committee may have also merged together other cases concerning that country, filed by authors other than the author of the three cases examined here, and discussed them simultaneously in its dialogues with the government representative. Because of the decision to merge cases together, the Committee fails to obtain information on specific individuals and, therefore, does not succeed in fully benefitting those individuals. ${ }^{26}$

\section{B. Cases Declared Inadmissible}

The second approach followed by the Committee was to declare cases inadmissible, according to one or more of the conditions prescribed in paragraph 14 (a) of the procedure. ${ }^{27}$ When following this approach, a positive outcome (such as the granting of passports, release of prisoners, etc.) was less likely. In addition, the Committee made its decisions rather hastily, often after the loose application of the admissibility requirements, and appeared more willing to accept government arguments as adequate without giving the authors a chance to respond.

Of the sixty-four cases, seventeen cases were declared inadmissible. In these seventeen cases, eleven countries were accused of human rights violations. ${ }^{28}$ These seventeen cases illustrate a common problem with the Committee's operations: the ease with which cases are declared inadmissible. In the seventeen cases, the Committee cited the following requirements as the basis for its decisions to declare the cases inadmissible:

26. For example, the last of the three Latin American cases was initially handled separately for two years (during four Committee sessions) before being fully merged with the other two cases. During those two years, some positive results were obtained. In that case, which involved an individual who "disappeared," the Committee was informed that the victim's family received legal and financial assistance stemming from the "disappearance." Despite this assistance, however, the victim was never located and his fate is still unknown.

27. See supra note 8 and accompanying text.

28. Bulgaria, Yugoslavia, and the former Soviet Union had two cases; China, Cuba, Czechoslovakia, Turkey, Uruguay, Romania, Italy, and Zaire were accused of violations in one case. 
(ii) the author must have reliable knowledge of the violations;

(iii) the communication must concern violations of human rights falling within UNESCO's field of competence;

(v) the communication must not be manifestly ill-founded;

(vii) the communication must not be entirely based on information disseminated through the media; and

(viii) the communication must be submitted within a reasonable timelimit.

The most obvious problem associated with the Committee's decisions in these cases is that the authors did not, with the possible exception of one case, submit any case to UNESCO that did not meet the admissibility requirements. When completing the official forms required by UNESCO, the case authors clearly stated the facts of each case and how they related to UNESCO's field of competence.

For example, under the section where the "rights allegedly violated" must be cited, the authors commonly cited Articles 19 (freedom of expression) of the Universal Declaration of Human Rights ${ }^{29}$ and the International Covenant on Civil and Political Rights. ${ }^{30}$ The authors also cited Universal Declaration Articles 18 (freedom of religion) and 20 (freedom of association), as well as Covenant Articles 18 (freedom of religion), 21 (freedom of assembly), and 22 (freedom of association). If a country was not party to the Covenant, authors cited articles contained in the Universal Declaration that related to UNESCO'S field of competence. In addition, under the section of the UNESCO form where the connection between the alleged violation and UNESCO's field of competence must be made, the information focused on authors, educators, scientists, and others who were detained, exiled, fired, etc., for their non-violent exercise of the right to freedom of expression and/or association. Also, when detailing the "facts of the claim" and the "means of redress," the authors kept their explanations short, concise, and related only to the facts of the case.

In effect, the content of the submissions met the admissibility requirements of the UNESCO procedure and, therefore, should have been declared admissible. The only possible exception was a 1988 case concerning an editor in a Middle Eastern country. This case was submitted because the author believed that the editor's thirty-six-year prison sentence was imposed for activities relating to the individual's job as editor-in-chief of a socialist

29. G.A. Res. 217A(III), adopted Dec. 10, 1948, U.N. Doc. A/810, at 71 (1948).

30. G.A. Res. 2200A(XXI), 21 U.N. GAOR Supp. (No. 16) at 52, U.N. Doc. A/6316 (1966), 999 U.N.T.S. 717, entered into force March 23, 1976. 
workers' publication. After the case was submitted to the Committee, however, the government responded that twenty-six years of the editor's sentence was a result of an armed robbery conviction. The organizational author had not heard of the armed robbery conviction until the case was submitted to the Committee. After reviewing the case during two sessions, the Committee decided it was manifestly ill-founded.

Even if the editor had been duly convicted for armed robbery (a conviction which the editor claimed was based on a confession extracted under the prevailing practice of torture in that country), the case still could have been declared admissible. In its response to the Committee, the government affirmed that ten years of the thirty-six-year sentence were imposed because the editor, among other things, encouraged illegal demonstrations and advocated revolutionary socialism. The author asked the Committee to investigate whether the armed robbery conviction was extracted under torture. The author also requested additional information on the other charges brought against the editor, which led to the additional ten-year sentence. The Committee did not provide any information about the additional charges brought against the editor. Rather, the Committee simply relayed to the author the government's conclusory denial that the editor's confession was extracted under torture. After taking note of the armed robbery conviction, the Committee dismissed the case.

There are several other problems associated with the Committee's operations and its decisions to declare cases inadmissible. First, the Committee's method for receiving communications is slow and cumbersome. The standard practice of UNESCO is to demand that a potential author inform the Director-General of his intent to submit a case (together with background information on the case) before a communication form can be sent to the author, who must then complete it and return it to UNESCO. This process alone takes between one to three weeks. Once these steps are completed, the Director-General is required to complete a fourstep information process. ${ }^{31}$ These four steps, particularly the first two, cause unnecessary delays in the consideration of communications. While contact between UNESCO and authors is warranted to ensure receipt of communications, this contact should not delay action on communications. If the completed forms do not reach the Committee a month prior to its semiannual sessions, consideration of the cases is delayed for six months. These steps may be necessary to inform authors who are unfamiliar with the procedure; however, they are not necessary for NGOs that regularly submit complaints.

Second, too often the Committee accepts at face value government

31. See supra text at note 8 . 
responses to the accusations brought against them, even though such responses often contain vague and inconsistent denials that human rights violations occurred. In turn, the Committee will delay making a decision on admissibility or will declare cases inadmissible based on its acceptance of such vague government responses.

Third, when declaring cases inadmissible, the Committee does so hastily. Of the seventeen cases declared inadmissible, the Committee made its decision after a small number of examinations: in five cases, the Committee made its decision after reviewing the cases twice; in ten cases, the Committee made its decision after only one review; in one case, the Committee made its decision after three reviews; and in one case, the Committee made its decision after four reviews.

In addition to hastily declaring these cases inadmissible, the Committee was less willing to allow the authors a chance to respond to its decisions or to the information provided by governments. This problem relates to a defect in the procedure. Case authors are not allowed to attend Committee meetings and therefore cannot examine the evidence provided by the governments concerned. Instead, the only information authors receive regarding government responses is contained in letters sent to authors by the Committee following action on their cases.

Two cases concerning an ethnic minority in an East European country demonstrate these problems. In the first case, filed in 1987, three individuals were arrested following their attempts to emigrate or to organize a meeting. One individual was sentenced to seven and one-half years imprisonment; the second individual was sentenced to five and one-half years; and the third to four and one-half years. The second case, concerning a journalist, was submitted at the same time as the first case. The journalist was imprisoned for publicly opposing government policies. Both cases were first examined in a 1987 session, in which the Committee delayed consideration at the government's request. At the following session, the Committee declared both cases inadmissible, apparently after merging the two cases together for consideration. The author of both cases requested clarification about the Committee's decision due to the confusion created by merging the cases together. The author also requested more information on the specific charges brought against the victims, and asked the Committee what its decisive factors were in dismissing the cases. The Committee simply replied that its decisions cannot be interpreted and that they are final.

In contrast to victims of the forty-two cases kept pending, victims cited in the seventeen cases declared inadmissible were less likely to be released. In the seventeen cases, thirty-three individuals were imprisoned, one individual was denied a promotion, and one individual was fired from his post. Of the thirty-five individuals, two had their sentences reduced and eight were released following action by the Committee. Of the remaining 
twenty-five individuals, ten remained imprisoned. The fate of the remaining fifteen individuals could not be determined, although it is likely they remained in jail.

Perhaps the most significant problem with the Committee's decision to declare certain cases inadmissible is that such decisions have the potential for causing further harm to the victims concerned. The labeling of a case as "manifestly ill-founded," for example, may be interpreted by some governments as a confirmation that the charges or convictions of the victims are appropriate. Moreover, some governments may worsen their treatment of victims whose cases are declared inadmissible in retaliation for having their case brought before UNESCO.

One way the UNESCO Committee could overcome many of these problems is by following the practice used by the Human Rights Committee, under the Optional Protocol to the International Covenant on Civil and Political Rights, ${ }^{32}$ in its handling of complaints. The Human Rights Committee will not issue a final decision on a case if the specific facts of the case are in dispute. ${ }^{33}$ The Human Rights Committee will, however, issue a final decision on cases if the facts are either uncontested or contested only by general denials. Recalling that UNESCO may not act as an "international judicial body" under paragraph 7 of the procedure, it can be concluded that when there are disputes over the facts of a case, the Committee is not able to judge which facts are correct and which are not. By requesting more information from the governments concerned, however, the Committee is acting as an international judicial body. Therefore, in cases where the governments vaguely deny that human rights violations have occurred, the Committee can request more information or declare such cases admissible. The Committee could also seek information by sending, on a more regular basis, diplomatic representatives to make direct contacts with governments or by seeking the assistance of the Director-General to undertake direct contacts.

\section{Cases Kept Pending Without Deciding Admissibility}

In the forty-two cases eventually deleted without being declared admissible, the Committee promoted some of the positive effects of its procedure. First, it declined to accept at face value government denials that human rights violations had occurred. Rather, the Committee was willing to request

32. See supra note 30 at 302 .

33. See Dominic McGoldrick, The Human Rights Committee: Its Role in the Development of the international Covenant on Civil and Political Rights 146-50 (1991). 
additional information from the governments concerned and to make appeals for clemency.

In fourteen of the forty-two cases eventually stricken after being held for some time, the Committee made a humanitarian appeal or urged that the victims receive clemency. In five of these cases, the Committee also requested that the UNESCO Director-General approach the governments concerned to secure their cooperation with the Committee. In one case, the Committee also requested that the UN Commission on Human Rights intervene on behalf of the victim during the previously scheduled visit of a special representative to the country concerned.

The above examples indicate a better approach taken by the Committee, as compared to its handling of cases promptly declared inadmissible. Such advantages, however, should be carefully scrutinized. First, although the Committee was more likely to request additional information from the governments, the requests were often vague and focused on whether domestic remedies had been exhausted and on the nature of criminal proceedings brought against the victims. Those requests for information were often repeated in subsequent sessions due to the governments' failure to cooperate, and came in response to detailed information on the victims' legal status provided by the authors who submitted the cases to UNESCO. ${ }^{34}$ In those cases, the Committee delayed consideration, rather than declaring the cases admissible.

Nonetheless, the release of victims (and other positive outcomes of cases) was more likely when the Committee kept their cases pending. In twenty-six of the forty-two cases, the countries released prisoners from prisons or re-education camps following action by the Committee. In three additional cases, the victims were freed before the Committee was able to examine their cases. In one case the victim was freed one year early. In another case filed on behalf of two individuals, one individual was released and one remained in prison. The remaining eleven resulted as follows: in one case an individual was returned from exile, in another case twenty-one individuals were rehired to their former posts and a license to publish was restored, and in three cases the three victims received their passports. In an additional case, the victim's citizenship was restored, although UNESCO was not a factor in the case. In the remaining five cases, the victims remained imprisoned, under house arrest or confined in re-education camps.

Even in cases where the Committee followed its predominant approach and the victims were eventually released, many victims remained impris-

34. Because they cannot attend Committee sessions, the authors cannot fully determine specific requests made by the Committee during its sessions. 
oned for several years, often under poor conditions and subjected to torture, while the Committee repeatedly considered their cases. Of the forty-two cases, the number of sessions during which the cases were examined ranged from one to ten. The average number of reviews per case was three Committee sessions or one and one-half years. At the high end of the scale, two cases were examined during seven Committee sessions (for three and one-half years), one case during eight sessions (for four years), two during nine sessions (four and one-half years), and one during ten sessions (five years). At the low end of the scale, eight cases were examined twice (one year), fourteen cases were examined once (six months), and two case were closed prior to a review by the Committee. Of the remaining twelve cases, three were examined during five sessions (two and one-half years), four were examined during four sessions (two years), and five were examined during three sessions (one and one-half years).

A second problem associated with these cases, one which the UNESCO Committee struck from consideration on the grounds that the prisoners had been released, is that the Committee often did not verify whether the victims were actually released. A simple statement by a government representative that a victim was or was scheduled to be released, was usually enough to satisfy the Committee, causing it to close a case permanently. Furthermore, once a case is closed, it apparently cannot be re-opened. Rather, a new communication, alleging new violations, must be submitted. In at least five of the sixty-four cases, the victims faced continued restrictions following their "release" from prison. In these cases, the authors specifically asked the Committee to verify whether the victims were truly released, and the Committee failed to comply.

A case concerning a well-known political activist who was imprisoned in a Middle Eastern country shows this problem. Initially, the individual was held for more than three years in pre-trial detention, often incommunicado. Later, the individual was tried and sentenced to death on unknown charges. The death sentence was commuted, but the individual remained imprisoned and in poor health.

During the Committee's examination of the case, the UN Commission on Human Rights was asked to intervene on the individual's behalf while a special representative made a previously scheduled visit to the country. During that mission, the Commission's representative visited the individual in prison and later informed the Committee that, contrary to the government's previous statements to the Committee, the person was in poor health as a result of torture.

The representative also reported that the government denied the prisoner's request to undergo surgery in a hospital located outside of the prison. Nonetheless, the Committee decided to strike the case and to determine it settled, in accordance with paragraph $14(a)(x)$ of the proce- 
dure. The decision was based upon the government representative's statement that the individual was released and residing in a nursing home, and appeared to ignore the information obtained by the UN Commission on Human Rights. The author of the submission was independently informed that the individual was being held in a nursing home, but faced continued restrictions on freedom of movement. In response, the author requested the Committee to verify this information, but was informed that the decision of the Committee to dismiss the case was final and not appealable.

To the Committee's credit, there were exceptions when it kept cases open until ascertaining that the victims were actually released, rehired, or granted passports. In 1983, a case was submitted to UNESCO concerning twelve persons in a South American country arrested after criticizing the government's economic policies. During the Committee's first review of the case, the representative of the government in question flatly defended the twelve arrests, causing the Committee to delay making a decision on admissibility. The case author later informed the Committee that the twelve persons had been released; however, the charges against them had not been dropped. During the following session, the Committee requested that the government provide information about the charges still being brought against the twelve persons. The Committee repeated this request at its subsequent session, even though the government confirmed that the twelve people were free. The Committee struck the case after receiving information that the charges had been dropped.

The South American case illustrates that by keeping cases open and repeating specific requests for information on victims the Committee can be effective. Unfortunately, the Committee's thorough handling of the South American case is a rarity, compared to its handling of the other sixty-three cases. Even in this particularly thorough case, the Committee neither stated that the victims' right to freedom of expression had been violated, nor did it seek to ensure that this right would be protected in the future.

The failure of the Committee to confront violations of freedom of expression and association was indicated in each of the sixty-four cases, of which fifteen concerned journalists, poets, authors, or publishers (including one newspaper), twenty-seven concerned students and teachers, and three concerned doctors. In the remaining nineteen cases other professions were represented, including religious leaders, former government officials, and participants in various types of public demonstration. In all sixty-four cases, the victims were arrested, exiled, or fired following publication of their writings, or following participation in strikes or other types of non-violent, public forms of expression. In some cases, victims were arrested simply for actual or alleged membership in an organization. In others, the victims were arrested after applying for exit visas (in conjunction with being well-known authors). 
In ten of the forty-two cases kept pending, the issue of freedom of expression was specifically addressed during the Committee's examination of the cases. In these cases, however, the Committee's questions focused on whether the victim had used or advocated violence. In response, the government representatives would make general replies that the victim used or incited violence without providing specific evidence of where or when such acts had occurred. Despite the vagueness of the governmental replies, the Committee failed to declare the cases admissible or to seek to ensure that the victims' right to freedom of expression would be restored, even when the author of the cases provided the Committee with documentation (consisting of judicial verdicts or the publications that caused a victim's arrest) that clearly showed that the victims did not use or advocate violence.

A case concerning two individuals in a Southeast Asian country exemplifies this problem. The first individual, a teacher who gave instruction in reading the Koran, was arrested after asking two pupils to display copies of two religious news bulletins. The second individual was arrested for distributing copies of a religious youth bulletin. Both persons were convicted on charges of subversion. Their case was examined during five Committee sessions before being stricken as a settled matter following the release of both persons. During the investigation, the government representative told the Committee that the persons had been duly sentenced for inciting hatred and violence in their dissemination of information. In response, the Committee requested more information from the government as to whether the victims used or advocated violence. The government representative failed to cite any occasion where violence had occurred, nor did the representative argue that the language in the bulletins specifically called for the use of violence. Rather, the government asserted that the simple act of distributing a religious bulletin had incited hatred and violence. Clearly the two individuals' right to freedom of expression was violated; nonetheless, the Committee failed to declare the case admissible and kept it pending until the victims were released.

The Committee protects the rights of prisoners and those accused to equal protection under the law by pursuing their release. These rights are contained in Articles 6-11 of the Universal Declaration of Human Rights, for example. These rights do not, however, fall under UNESCO's specific field of competence, which includes Articles 18 (freedom of religion), 19 (freedom of expression), 20 (freedom of association), 26 (freedom of education), and 27 (freedom of scientific advancement) of the Universal Declaration.

On the one hand, this aspect of the Committee's operations has two benefits. Most obviously, some of the victims' rights are restored. The procedure can also contribute to the protection of certain human rights. On the other hand, the Committee fails to achieve the protection of rights 
relating to UNESCO's field of competence, particularly the right to freedom of expression. The release of a victim does, however, indirectly protect his freedom of expression, even if he is still not permitted to publish, write, or demonstrate.

\section{CONCLUSIONS AND RECOMMENDATIONS}

The adoption of 104 EX/Decision 3.3 in 1978 was an impressive effort by UNESCO to follow the lead of the United Nations and the Council of Europe in developing a procedure for handling individual cases of human rights violations. The UNESCO procedure was an improvement over the UN procedures that existed at the time, and the new procedure contained some of the more useful elements of the European procedures. Some procedural advantages included its wide access to individuals, groups, and NGOs; the separate handling of each case throughout the procedure, rather than merging cases into a "situation"; and the power of the Executive Board to appoint public fact-finding missions to investigate large-scale "questions" of human rights abuses.

Although an improvement at the time of its adoption, the UNESCO procedure has not evolved the way the other UN complaint procedures have under ECOSOC resolutions 1235 and 1503, under the practices of the UN Commission on Human Rights, ${ }^{35}$ or the work of the Human Rights Committee. The failure of the procedure's evolution is a result of several

35. Under the authority of ECOSOC resolution 1235, the UN Commission on Human Rights has established a number of country rapporteurs, working groups, and similar procedures for dealing with widespread violations of human rights. For example, the Commission has mounted highly visible fact-finding efforts in the last several years in regard to the following countries: Cambodia (special representative, 1993), Cuba (delegation of six members of the Commission, 1988; Secretary-General to maintain contacts, 1989present; special rapporteur, 1992-present), El Salvador (special representative, 19811991; expert, 1992-present), Equatorial Guinea (special rapporteur, 1979; expert, 1980, 1984, 1991-1992; special rapporteur, 1993), Guatemala (special rapporteur, 19821985; special representative, 1986-1988; expert, 1990-present), Haiti (special rapporteur, 1992-present), Iraq (special rapporteur, 1991-present), Myanmar (special rapporteur, 1992-present), Palestine (special rapporteur, 1993), Romania (special rapporteur, 19891991), Somalia (expert, 1993), Sudan (special rapporteur, 1993), and former Yugoslavia (special rapporteur, 1992-present).

In addition, at each of its annual sessions, the UN Commission on Human Rights has adopted resolutions or taken other public actions in regard to a wide variety of country situations in which there are serious human rights violations. For example, at its 1993 session the Commission was able to establish fact-finding mechanisms, express specific concerns, or otherwise respond to the situation in Afghanistan, Albania, Bahrain, Bougainville, Cambodia, Chad, Cuba, Cyprus, East Timor, Equatorial Guinea, El Salvador, Estonia, Georgia, Haiti, Iran, Israel and Occupied Territories, Latvia, Morocco (Western Sahara), Myanmar, Romania, Rwanda, Somalia, South Africa, Sri Lanka, Sudan, Tadjikistan, Togo, and Zaire. See generally, Reed Brody, Penny Parker, \& David 
characteristics of UNESCO, as well as the implementation of the procedure by the Committee on Conventions and Recommendations. The human rights procedure of UNESCO is only a very small part of that organization's work, and it receives very little attention. Indeed, the UNESCO Committee has functioned in nearly total obscurity. Due to its excessive secrecy and the lack of publicity about its work, the Committee has not been under any significant pressure to improve its procedures. Also, the Committee has not learned from the procedural improvements made by other human rights bodies, but has functioned in almost total isolation. Further, during much of the period since 1978, UNESCO has been undergoing membership and budgetary difficulties in which human rights issues and the work of the Committee on Conventions and Recommendations have had a very low priority.

Nonetheless, nongovernmental organizations have found ways to use the UNESCO procedure for the benefit of authors, educators, scientists, and other persons who suffer human rights violations within UNESCO's purview. In the cases of individuals, the procedure has contributed to the individuals' release, re-employment, or receipt of a passport. Unfortunately, for ninety-seven individuals the procedure was too political, featured progovernmental biases that resulted in their continued imprisonment, or failed to guarantee their rights relating to UNESCO's field of competence-most importantly freedom of expression.

Although UNESCO's March 1993 report left little indication that UNESCO's Executive Board will modify the operations of the procedure, human rights activists and users of the procedure recognize the need for reform. The following are recommendations, which are put forth for the purposes of public debate and consideration. ${ }^{36}$

1. The Committee on Conventions and Recommendations needs to be made less political. The Committee consists of twenty-four members appointed by member governments. Although every member may attend

Weissbrodt, Major Developments in 1990 at the UN Commission on Human Rights, 12 Hum. Ris. Q. 559 (1990); Penny Parker \& David Weissbrodt, Major Developments at the UN Commission on Human Rights in 1991, 13 Hum. RTs. Q. 573 (1991); Maria Bartolomei, Gross and Massive Violations of Human Rights in Argentina, 1976-1983: An Analysis of the Procedure Under ECOSOC Resolution 1503 (1991); Nowak, supra note 19; Joe Pitts \& David Weissbrodt, Major Developments at the UN Commission on Human Rights in 1992, 15 Hum. Ris. Q. 122 (1993).

36. The suggestions are influenced by the results of the "Working Seminar on UNESCO Human Rights Procedures," convened on 12 Sept. 1984, at the Carnegie Institution (Washington, D.C.). The two-day seminar was attended by human rights activists, users of the procedure, and representatives of UNESCO. For a report on the seminar, see international Human Richts law Group, Working Seminar on Unesco Human Richts Procedure (1984). 
Committee meetings, in practice about eighteen usually attend. Moreover, members may be motivated to attend meetings only if communications relating to their governments or allies of their governments are being considered.

The size of the Committee should be reduced from twenty-four members to five members. A smaller Committee could better function as a less political, expert body whose only responsibility is examining human rights violations. Alternatively, a sub-Committee of five members could meet between the regular sessions of the Committee. Such a sub-Committee could handle the exchange of information between authors and governments, and make decisions on admissibility.

2. The Committee should establish an expedited procedure for organizational authors that regularly submit complaints, so that some of the unnecessary delay can be avoided. These regular users of the procedure do not need to have the procedure explained each time they submit a complaint.

3. The existing UNESCO procedure promises an exchange of views between case authors and governments. The Committee's habit of accepting governmental denials that human rights violations occurred, in addition to its quick dismissal of cases without giving authors a chance to respond, prevent that exchange of views. In the future, UNESCO should follow the lead of the Human Rights Committee. The Human Rights Committee will not issue a decision on a case if the specific facts of the case are in dispute. The Human Rights Committee will, however, issue a final decision on cases if the facts are either uncontested or contested only by general denials. UNESCO should also consider allowing authors of cases to attend meetings of the Committee, so they may respond directly to government replies.

4. The Committee must make a clear distinction between the admissibility phase of the procedure and the later consideration of the merits of cases. The procedure's flexible mandate to bring about friendly solutions to cases should not interfere with the judicial-like requirements that cases must meet to be declared admissible.

5. The Committee must allow for the emergency consideration of cases, especially those cases in which the victims are tortured or are suffering from serious health problems. The "friendly offices" power of the DirectorGeneral could be used more frequently in such cases. Also, the Executive Board could authorize the chair of the Committee to take provisional measures to avoid harm to victims, while understanding that such measures would not prejudice the Committee's disposition of the cases.

6 . In its consideration of cases, a simple statement by a government that a victim is (or is scheduled to be) released has been enough during some periods to satisfy the Committee, causing it to close a case permanently. In 
the future, the Committee should consistently verify such government statements with authors before closing cases.

7. Rather than simply assuring that victims are released from prison and then closing cases, the Committee should address all of the violations alleged. In particular, the right to freedom of expression must be better addressed by the Committee. In these cases the Committee should acknowledge that such a violation occurred and make recommendations designed to prevent future violations.

8. The Committee must use the ability of the Director-General to appoint fact-finding missions to examine "questions" of large-scale human rights violations. So far, such a mission has never been sent.

9. The Committee should systematically make available information about the results achieved under the complaint procedure, so that its effectiveness can be evaluated more fully.

This article has attempted to assess UNESCO's effectiveness in advancing the protection of human rights through the UNESCO procedure for reviewing complaints from authors, educators, scientists, and other persons who suffer human rights violations within UNESCO's purview. This study of sixty-four cases that have been subjected to the UNESCO procedure has reaffirmed many of the problems with the procedure, which have been made known to UNESCO since at least 1984. The continuing existence of these problems underscores the need for UNESCO to modify its procedure so that the international protection of human rights can be improved. In the meantime, however, the UNESCO procedure continues to be available as one of the international procedures under which complaints of human rights violations may be submitted. In this regard, individuals and NGOs should continue to take advantage of the procedure as one of the many approaches available to protect international human rights. As new avenues for protecting human rights develop, ${ }^{37}$ an unmodified UNESCO procedure

37. For example, during the period 1980 to the present, the UN Commission on Human Rights has developed an impressive set of thematic and country procedures allowing rapporteurs or working groups to seek and receive information on human rights violations. Thematic rapporteurs or working groups respond to the information they receive, in an effort to eliminate certain human rights violations. Several of the thematic procedures overlap directly with the work of the UNESCO Committee. The thematic procedures include the Working Group on Enforced or Involuntary Disappearances (established in 1980); the Special Rapporteur on summary or arbitrary executions (1982); the Special Rapporteur on torture (1985); the Special Rapporteur on religious intolerance (1986); the Special Rapporteur on mercenaries (1987); the Special Rapporteur on the sale of children (established in 1990 and recognized as a thematic procedure in 1992); the Working Group on Arbitrary Detention (1991); the Special Representative on internally displaced persons (established in 1992 and recognized as a thematic procedure in 1993); the Special Rapporteur on racism and xenophobia (1993); the Special Rapporteur on freedom of opinion and expression (1993); and the Working Group on the Right to 
risks losing its place among the effective alternatives for ensuring international human rights.

Development (1993). See generally, J. Daniel Livermore \& B. G. Ramcharan, "Enforced or Involuntary Disappearances": An Evaluation of a Decade of United Nations Action, CAN. Hum. Ris. Y.B. 217 (1990); Nowak, supra note 19, at 42-45; Reed Brody, The United Nations Creates a Working Group on Arbitrary Detention, 85 AM. J. INT'L L. 709 (1991); Pitts \& Weissbrodt, supra note 35, at 158-75.

The Working Group on Arbitrary Detention, created by the Commission in 1991, most clearly reflects the evolution of UN procedures as to which the UNESCO Committee has been left woefully behind. The Commission assigned the Working Group on Arbitrary Detention the task of "investigating cases of detention imposed arbitrarily or otherwise inconsistently with the relevant international standards set forth in the Universal Declaration of Human Rights or in the relevant international legal instruments." See C.H.R. res. 1991/42, U.N. Doc. E/CN.4/1991/91, at 106 (1991). The Working Group was given a three-year mandate which substantially overlaps with the role of the UNESCO Committee in that both can deal with people who have been detained for reasons relating to freedom of expression.

In its 1993 report to the Commission on Human Rights, however, the Working Group on Arbitrary Detention indicated that it had begun to take an adjudicative approach to its cases. The Working Group stated, "The Group takes the view that .. . investigation should be of an adversarial nature." U.N. Doc. E/CN.4/1993/24, at 102 (1993). As such, the Working Group on Arbitrary Detention renders decisions and makes recommendations on the individual complaints it accepts.

In October 1991, after its first session, the Working Group on Arbitrary Detention sent communications regarding 223 alleged cases of arbitrary detention to seventeen governments. $I d$. at 7 . After its second session, the Working Group sent another fifteen communications to nine governments, including one "urgent action" communication to the government of the Lao People's Democratic Republic. After its third session, the Working Group sent thirty-four communications to twenty-four governments. The Group also sent eleven "urgent action" messages to ten governments. In contrast to the UNESCO Committee, the Working Group on Arbitrary Detention publishes detailed annual reports of its work.

There is yet another UN procedure which will directly overlap and may eventually eclipse the work of the UNESCO Committee. The Commission on Human Rights initiated in 1993 a three-year mandate for a Special Rapporteur on freedom of opinion and expression. The Special Rapporteur must "gather all relevant information wherever it may occur of discrimination against, threats or use of violence and harassment, including persecution and intimidation, directed at persons seeking to promote the exercise of the right to freedom of expression and opinion." The Special Rapporteur must also, "as a matter of high priority, ... gather all relevant information... of discrimination against, threats or use of violence and harassment, including persecution and intimidation, against professionals in the field of information seeking to exercise or to promote the exercise of the right to freedom of expression and opinion ..." C.H.R. res. 1993/45, U.N. Doc. E/CN.4/1993/L.11/Add.5, at 57 (1993). The Special Rapporteur on freedom of opinion and expression will probably follow the approach established by the other thematic procedures and particularly the Working Group on Arbitrary Detention in adjudicating cases. 